\title{
(5)

\section{Mens vi venter på nye retningslinjer for behandling av korsryggsmerter}

DEBATT

\section{RIKKE MUNK}

E-post: rikke@oslomet.no Rikke Munk er fysioterapeut og ph.d.-stipendiat ved Institutt for fysioterapi, OsloMet storbyuniversitetet.

Forfatter har fylt ut ICMJE-skjemaet og oppgir ingen interessekonflikter.

\section{KJERSTI STORHEIM}

Kjersti Storheim er fysioterapeut, ph.d. og professor ved Forsknings- og formidlingsenheten for muskelskjeletthelse (FORMI), Nevroklinikken, Oslo universitetssykehus og Institutt for fysioterapi, OsloMet - storbyuniversitetet.

Forfatter har fylt ut ICMJE-skjemaet og oppgir ingen interessekonflikter.

\section{JOHN-ANKER ZWART}

John-Anker Zwart er lege, ph.d. og professor ved Avdeling for forskning og utvikling, Nevroklinikken, Oslo universitetssykehus og Medisinsk fakultet, Universitetet i Oslo.

Forfatter har fylt ut ICMJE-skjemaet og oppgir ingen interessekonflikter.

\section{JAN HARTVIGSEN}

Jan Hartvigsen er kiropraktor, ph.d. og professor ved Institut for Idræt og Biomekanik, Syddansk universitet, Odense.

Forfatter har fylt ut ICMJE-skjemaet og oppgir ingen interessekonflikter.

\section{TRYGVE SKONNORD}

Trygve Skonnord er lege og ph.d.-stipendiat ved Avdeling for allmennmedisin, Institutt for helse og samfunn, Universitetet i Oslo.

Forfatter har fylt ut ICMJE-skjemaet og oppgir ingen interessekonflikter.

\section{$\varnothing R J A N$ NESSE VIGDAL}

Ørjan Nesse Vigdal er fysioterapeut og ph.d.-stipendiat ved Institutt for fysioterapi, OsloMet storbyuniversitetet.

Forfatter har fylt ut ICMJE-skjemaet og oppgir ingen interessekonflikter.

\section{MARGRETH GROTLE}

Margreth Grotle er fysioterapeut, ph.d. og professor ved Institutt for fysioterapi, OsloMet storbyuniversitetet og Forsknings- og formidlingsenheten for muskelskjeletthelse (FORMI), Oslo universitetssykehus.

Forfatter har fylt ut ICMJE-skjemaet og oppgir ingen interessekonflikter. 
korsryggsmerter. Det koster mye, og mange pasienter sykeliggjøres. Vårt behandlingssystem kjører på en ineffektiv autopilot.

Våren 2018 ble det publisert en artikkelserie om korsryggsmerter i tidsskriftet The Lancet (1-3). Under ledelse av professor Rachelle Buchbinder redegjorde en tverrfaglig internasjonal ekspertgruppe på 29 forskere for dagens kunnskapsstatus og satte søkelys på at det eksisterer store gap mellom anbefalinger og praksis. Til tross for at internasjonale retningslinjer (4-6) generelt gir ensrettede anbefalinger, undergår altfor mange ryggpasienter undersøkelser og behandling som ikke har støtte i forskningsbasert litteratur. Som klinikere må vi ta tak i disse utfordringene, men også Helsedirektoratet må på banen. Våre nasjonale kliniske retningslinjer for korsryggsmerter ble sist revidert i 2007 (7). Mye har skjedd siden da, og leser vi Lancet-serien, ser vi spesielt to sentrale ankepunkter til våre nasjonale retningslinjer. De gjelder bruk av bildediagnostikk og medikamentell behandling.

\section{Bruken av bildediagnostikk må reduseres}

Våre nasjonale retningslinjer anbefaler bruk av bildediagnostikk ved mistanke om såkalte «røde flagg» og ved symptomer uten bedring etter 4 til 6 uker (7). Forfatterne av Lancetserien anbefaler derimot ikke rutinemessig bruk av bildediagnostikk (1) og mener at vi med noen få unntak skal ha mer is i magen. Grunnlaget for anbefalingen forklares med at det ikke er evidens for at bildediagnostikk uten klar indikasjon bedrer det kliniske forløpet til ryggpasienter, og at de fleste «røde flagg» har veldig lav spesifisitet og fører til unødvendig bildediagnostikk (1). Omtrent $80 \%$ av personer med akutte korsryggsmerter har minst ett «rødt flagg», til tross for at bare om lag $1 \%$ har en alvorlig underliggende patologisk tilstand $(1,8)$.

Våre nasjonale kliniske retningslinjer for korsryggsmerter ble sist revidert i 2007

\section{Mindre medikamentell behandling}

Medikamentell behandling står i våre nasjonale retningslinjer sentralt $\mathrm{i}$ grunnbehandlingen av uspesifikke korsryggsmerter og korsryggsmerter med nerverotsaffeksjon. Internasjonale retningslinjer og Lancet-serien anbefaler derimot ikke medikamentell behandling som en del av grunnbehandlingen $(1-3,5)$. Ved uspesifikke korsryggsmerter med eller uten radierende smerter samt radikulopati uten alvorlig eller progredierende kraftnedsettelse består anbefalt grunnbehandling i å gi råd om å forbli aktiv, informere om ryggplagers vanlige forløp og prognose og berolige pasienten (2). I tillegg anbefales veiledet trening og kognitiv atferdsterapi ved langvarige plager. Spinal manipulasjon, massasje, akupunktur og medikamentell behandling anbefales eventuelt som supplement til grunnbehandlingen (2). Skal medikamentell behandling benyttes, bør ikke-steroide antiinflammatoriske midler (NSAID) være førstevalg, men da med lavest mulig effektiv dose over kortest mulig periode. Bruk av paracetamol frarådes på grunnlag av manglende evidens for effekt (2).

\section{Veien videre}

Ryggplager er den enkeltlidelsen som "plager flest og koster mest». I et pasient- og samfunnsperspektiv er vi derfor nødt for å ta tak i disse utfordringene. Våre nasjonale retningslinjer skal gi klinisk og helseøkonomisk beslutningsstøtte og være basert på den beste tilgjengelige kunnskapen. Våre nasjonale retningslinjer bør oppdateres. Eller kanskje vi rett og slett skal legge dem til side og heller se til internasjonale retningslinjer? Det er på tide å skru av autopiloten. 
1. Hartvigsen J, Hancock MJ, Kongsted A et al. What low back pain is and why we need to pay attention. Lancet 2018; 391: 2356-67. [PubMed][CrossRef]

2. Foster NE, Anema JR, Cherkin D et al. Prevention and treatment of low back pain: evidence, challenges, and promising directions. Lancet 2018; 391: 2368-83. [PubMed][CrossRef]

3. Buchbinder R, van Tulder M, Öberg B et al. Low back pain: a call for action. Lancet 2018; 391: 2384-8. [PubMed][CrossRef]

4. Stochkendahl MJ, Kjaer P, Hartvigsen J et al. National Clinical Guidelines for non-surgical treatment of patients with recent onset low back pain or lumbar radiculopathy. Eur Spine J 2018; 27: 60-75. [PubMed][CrossRef]

5. Qaseem A, Wilt TJ, McLean RM et al. Noninvasive treatments for acute, subacute, and chronic low back pain: A clinical practice guideline from the American College of Physicians. Ann Intern Med 2017; 166: 514-30. [PubMed][CrossRef]

6. National Guideline Centre (UK). Low back pain and sciatica in over 16s: Assessment and management. London: National Institute for Health and Care Excellence, 2016. https://www.nice.org.uk/guidance/ng59 Lest 31.3.2020.

7. Lærum E, Brox JI, Storheim K et al. Nasjonale kliniske retningslinjer. Korsryggsmerter - med og uten nerverotaffeksjon. Formidlingsenheten for muskel- og skjelettlidelse, 2007.

https://www.muskelskjeletthelse.no/wp-content/uploads/2016/o6/Nasjonale-kliniske-retningslinjer-k orsryggsmerter-2007-Fullversjon.pdf Lest 31.3.2020.

8. Henschke N, Maher CG, Refshauge KM et al. Prevalence of and screening for serious spinal pathology in patients presenting to primary care settings with acute low back pain. Arthritis Rheum 2009; 60:3072-80. [PubMed][CrossRef]

Publisert: 20. mai 2020. Tidsskr Nor Legeforen. DOI: 10.4045/tidsskr.20.0181 Mottatt 28.2.2020, godkjent 31.3.2020.

(C) Tidsskrift for Den norske legeforening 2020. Lastet ned fra tidsskriftet.no 